
\title{
R Research Square \\ Identification and Biological Characteristic Analysis of Pythium aristosporum Causing Rice Seedling Blight in Northeast China
}

Jinxin Liu

Northeast Agricultural University https://orcid.org/0000-0002-4621-8553

Chuzheng Xu

Northeast Agricultural University

Wenbo Han

Northeast Agricultural University

Yonggang Li ( $\square$ neaulyg@126.com )

Northeast Agricultural University https://orcid.org/0000-0003-4582-2473

Original article

Keywords: Pythium aristosporum, Identification, Biological characteristic, Host range determination, Sensitivity test

Posted Date: October 23rd, 2020

DOI: https://doi.org/10.21203/rs.3.rs-95446/v1

License: (9) (1) This work is licensed under a Creative Commons Attribution 4.0 International License. Read Full License 


\section{Abstract}

Background: Rice seedling blight caused by diverse pathogenic microorganism occurs worldwide, and it is currently the most important seedling disease affecting rice production in Northeast China. Understanding the biological characteristics, host range, and fungicide sensitivity of pathogens causing rice seedling blight has important theoretical and practical significance for further exploring occurrence of the disease and for making targeted prevention and control measures.

Results: 10 isolates of Pythium spp. were obtained from rice seedling blight, according to Koch's postulates, in Heilongjiang Province, China. Based on morphology, molecular biology, and phylogenetic tree analyses, the obtained fungal isolates were identified as $P$. aristosporum. The biological characteristics of $P$. aristosporum showed that the optimum fermentation conditions were as follows: temperature, $25^{\circ} \mathrm{C}$; initial $\mathrm{pH}, 6$; photoperiod, $24 \mathrm{~h}$ light; and carbon and nitrogen sources, starch and glycine, respectively. P. aristosporum causing rice seedling blight had a wide range of hosts and could infect tomato (Solanum lycopersicum), carrot (Daucus carota L.), sweetpotato (Ipomoea batatas), cucumber (Cucumis sativus L.), and zucchini (Cucurbita pepo L.), as well as seedlings of broad bean (Vicia faba L.), red bean (Vigna angularis), snailflower (Lablab purpureus (Linn.)Sweet), soybean (Glycine max), mung bean (Vigna radiata), kidney bean (Phaseolus vulgaris), and hyacinth bean (Dolichos lablab L.); however, it could not infect cabbage (Brassica oleracea L.) and maize (Zea mays L.) seedlings. We also evaluated $P$. aristosporum sensitivity to five commonly used fungicides and found that fludioxonil $\left(\mathrm{EC}_{50}=0.0731 \mu \mathrm{g} / \mathrm{ml}\right)$ was the most effective against $P$. aristosporum.

Conclusion: To our knowledge, this is the first report of $P$. aristosporum causing rice seedling blight in China. Fludioxonil is a relatively sensitive chemical fungicide against $P$. aristosporum. $P$. aristosporum causing rice seedling blight has a good environmental adaptability and a wide range of hosts, which poses a great threat to rice seedling production. Occurrence of the new disease caused by $P$. aristosporum should give full consideration for the use of proper disease management to protect rice.

\section{Background}

Rice, wheat, and maize are the three major staple crops worldwide (Yu and Tian 2018; Shindell et al. 2019); among these, rice is the most important cultivated cereal and food crop in China, and it plays an important role in agriculture (Cao 2020; Liu 2017). Heilongjiang Province is the northernmost rice-growing region and is one of the largest commercial Japonica rice production bases in China (Meng et al. 2008). Therefore, ensuring the sustainability of rice production systems in this area is important to global food security and protecting economic livelihoods (Motschenbacher et al. 2014). Rice seedling blight is a serious disease that poses an emerging threat to global rice production. In China, the incidence of this disease, which delays growth of rice seedlings and reduces rice grain yield, has recently been increasing every year (Li et al. 2016). Rice seedling blight disease is caused by several pathogens and is greatly influenced by low temperature (Liu et al. 2004). Because Heilongjiang Province is located in the cold 
northern region of China, incidence of rice seedling blight in this province is significantly higher than that in other rice planting areas.

The use of chemicals remains the most effective way to control rice diseases (Liu et al. 2020); however, it is relatively ineffective for protecting plants from seedling blight mainly because the pathogens responsible for rice seedling blight are complex and vary based on location (Riera-Ruiz et al. 2018). There are diverse rice seedling blight pathogens in different regions, soil types, and periods; these include Fusarium spp., Pythium spp., Rhizopus spp., Curvularia lunata, Burkholderia glumae, Burkholderia plantarii, and Trichoderma spp. (Aye et al. 2008; Rush 1977; Wang et al. 2016; Whithey 1982; Yoneyama et al. 1998; Ma et al. 2019; Verma et al. 2018). Thus, blindly selecting chemical agents while ignoring the pathogenic species is relatively ineffective for protecting plants from seedling blight. As such, clarifying species and biological character of pathogens causing rice seedling blight is essential for developing effective disease control measures (Gao et al. 2001) that ensure a high and stable yield of rice.

Our team found a novel pathogenic fungus in the process of studying the population structure of fungi causing rice seedling blight in Heilongjiang Province. In this study, we aimed to identify the pathogenic factors causing rice seedling blight and to analyze their biological characteristics, host range, and sensitivity to common fungicides. The results presented in this study may help researchers develop viable disease control strategies in the future.

\section{Results}

\section{Disease symptoms and pathogenicity}

In May 2019, diseased rice plants (cv. Suigeng 18) showing symptoms of withered tips, chlorosis, stunting, yellow leaves, leaf drop, crown rot, and inhibited root growth, were observed in Suihua City $\left(46.63^{\circ} \mathrm{N} 126.98^{\circ} \mathrm{E}\right)$, Heilongjiang Province, China. In this city, the soil is mainly a black sandy clay, with a soil organic matter content of $4-5 \%$. Disease incidence was $10-15 \%$ in the three fields sampled ( $3 \mathrm{ha}$ ). Ten isolates different from known pathogens were obtained from this batch of samples and had similar characteristics. According to Koch's postulate, these 10 isolates were the pathogens of rice seedling blight.

\section{Identification of isolates}

The colonies of 10 isolates developed dense, aseptate, cottony, and white hyphae. The sporangia were either finger-like or lobe-like, germinating to produce germ tubes and produce zoospores at $10-15^{\circ} \mathrm{C}$. The resting spore was spherical, with a diameter of 9-12 $\mu \mathrm{m}$. The oogonium was subglobose, with a diameter of 19-35.5 $\mu \mathrm{m}$ (average $27.2 \mu \mathrm{m}$ ). The antheridium was clavate or curved neck, approximately $15 \mu \mathrm{m} \times 6$ $\mu \mathrm{m}$ and in contact with the oogonium at the top. Each oogonium has 3-10 antheridia. The oospore was spherical, smooth and aplerotic, with a diameter of 13.5-26.3 $\mu \mathrm{m}$ (average $19.9 \mu \mathrm{m}$ ). Each oogonium has 1-2 oospores. Based on their cultural and micro-morphological characteristics, the 10 isolates were identified as Pythium spp. (van der Plaats-Niterink 1981). 


\section{Molecular identification}

Genomic DNA from representative isolates JS22 and SH1 were extracted and the internal transcribed spacer regions (ITS) were amplified with the ITS1 and ITS4 primers.

PCR products were sequenced and deposited in GenBank (accession no. MT337429.1 and MT337436.1). BLAST analysis showed that the obtained sequence for the ITS amplicon shared $95 \%$ and $95 \%$ similarity with P. aristosporum voucher CBS_263.38 (accession no. AY598627.2) and P. arrhenomanes voucher CBS_324.62 (accession no. AY598628.1), respectively. They belonged to the same evolutionary branch as $P$. aristosporum and $P$. arrhenomanes, and the similarity was as high as $95 \%$ (Fig 1$)$. The isolates were identified as $P$. aristosporum based on the fact that $P$. aristosporum has aplerotic oospores and less antheridia per oogonium than $P$. arrhenomanes (van der Plaats-Niterink 1981).

Based on morphological characteristics, molecular sequence data, and phylogenetic tree analysis, the 10 isolates were finally identified as $P$. aristosporum.

\section{Biological characteristics}

$P$. aristosporum can grow in the 4.0-10.0 pH range, and the differences were significant among the treatments $(P<0.05)$, with the optimum $\mathrm{pH}$ value for mycelial growth determined to be 6.0 (Fig. 2-A). P.aristosporum can grow in the temperature range of $10-35^{\circ} \mathrm{C}$, and the differences were significant among the treatments $(P<0.05)$, with the optimum temperature for mycelial growth determined to be $25^{\circ} \mathrm{C}$ (Fig. 2-B). P.aristosporum mycelium can grow in various light conditions, and the differences were significant $(P<0.05)$, with the optimum photoperiod for mycelial growth determined to be $24 \mathrm{~h}$ light (Fig. 2-C). P.aristosporum can grow on media with different nitrogen sources, and the differences were significant among the treatments $(P<0.05)$, with the optimal nitrogen source determined to be glycine (Fig. 2-D). P.aristosporum can grow on media with different carbon sources, and the differences were significant among the treatments $(P<0.05)$, with the optimal carbon source determined to be starch medium (Fig. 2-E).

\section{Host range determination}

P. aristosporum can infect tomato, carrot, sweet potato, cucumber, and zucchin, as well as seedlings of broad bean, red bean, snailflower, soybean, mung bean, kidney bean, and hyacinth bean; conversely, cabbage and maize seedlings showed no signs of infection. Moreover, the disease in mung bean was severe, whereas the control plant seedlings were asymptomatic (Fig. 3).

\section{Sensitivity test}

As shown in Table 1, the $\mathrm{EC}_{50}$ value of fludioxonil was the lowest at $0.0731 \mu \mathrm{g} / \mathrm{ml}$, followed by prochloraz and carbendazim, with $\mathrm{EC}_{50}$ values of $0.2391 \mu \mathrm{g} / \mathrm{ml}$ and $1.0281 \mu \mathrm{g} / \mathrm{ml}$, respectively. $\mathrm{EC}_{50}$ values of hymexazol and azoxystrobin were higher, which were $8.0474 \mu \mathrm{g} / \mathrm{ml}$ and $11.0102 \mu \mathrm{g} / \mathrm{ml}$, respectively. 
Results showed that fludioxonil had the strongest inhibitory effect on $P$. aristosporum, whereas azoxystrobin had the weakest inhibitory effect.

Table 1

The $\mathrm{EC}_{50}$ of common chemical agents to Pythium aristosporum in viro

\begin{tabular}{|llll|}
\hline $\begin{array}{l}\text { Chemical } \\
\text { agents }\end{array}$ & Virulence regression equation $(\mathrm{y}=)$ & Coefficient correlation $(r)$ & $\begin{array}{l}\mathrm{EC}_{50} \\
\left(\mu \mathrm{g} \cdot \mathrm{mL}^{-1}\right)\end{array}$ \\
\hline Hymexazol & $4.1829+0.9022 \mathrm{x}$ & 0.9821 & 8.0474 \\
\hline Fludioxonil & $6.2323+1.0847 x$ & 0.9686 & 0.0731 \\
\hline Prochloraz & $5.3575+0.5753 x$ & 0.9852 & 0.2391 \\
\hline Carbendazim & $4.9901+0.8243 x$ & 0.9078 & 1.0281 \\
\hline Azoxystrobin & $3.6104+1.3338 x$ & 0.9949 & 11.0102 \\
\hline
\end{tabular}

\section{Discussion}

Rice seedling blight has been responsible for severe decreases in rice yield and quality in many countries (Baek et al. 2019; Imolehin 1983). There are various complex pathogens that cause rice seedling blight, with previous studies identifying Fusarium verticillioides and Xanthomonas oryzae pv. oryzae in India (Ahuja et al. 2019; Verma et al. 2019); Burkholderia glumae in Guayaquil, Ecuador, and Korea (Riera-Ruiz et al. 2018; Nguyen et al. 2017); Burkholderia plantarii in China (Qian et al. 2016; Wang et al. 2016); and $P$. arrhenomanes in the Philippines (Van and Hofte 2013). In addition, Furuya et al (2003) found $P$. aristosporum could affect the growth of rice seedlings in the Japan. However, to the best of our knowledge, this is the first study describing $P$. aristosporum as a causal agent of rice seedling blight in Northeast China.

Historically, the key for identifying Pythium species is based on morphological characteristics (van der Plaats-Niterink 1981; Mostowfizadeh-Ghalamfarsa and Banihashemi 2005). However, this can be supplemented by molecular identification, which is more confirmative especially when there are overlapping morphological characteristics that make it difficult to determine species and often make identification time-consuming (Alaei and Rostami. 2013; Naima et al. 2020). The internal transcribed spacer (ITS) sequence is a widely used DNA region with good resolution and is commonly used for the molecular identification of Pythium spp. (Klemsdal et al. 2008; Robideau et al. 2011). In past studies, Rojas et al. (2016) used the ITS region of the rDNA to identify the Pythium genus and species associated with soybean seedlings; Lookabaugh et al. (2017) used the ITS region of the rDNA gene to identify three Pythium species isolated from stunted wheat; Ling et al (2018) used the universal primers ITS1/ITS4 to identify $P$. arrhenomanes isolated from rice in China. In this study, traditional morphological identification of the isolates were carried out, and then the ITS1/ITS4 primers were used to further verify the results. 
Finally, a phylogenetic tree was constructed to ensure the accuracy and reliability of the identification results.

Pythium activity is easily affected by environmental factors such as light, temperature, and pH (Huang and Su 2007; Guo et al. 2019; Li and Zhang 2020). Additionally, different nitrogen and carbon sources can also affect Pythium isolates growth (Foley and Deacon 1986; Temgot and Xu 1996). Therefore, determining $P$. aristosporum biological characteristics have contributed to understanding the reason behind its prevalence and has provided a theoretical basis for formulating rice seedling blight control measures. In this study, the biological characteristics of $P$. aristosporum showed that the optimum fermentation conditions were as follows: temperature, $25-30{ }^{\circ} \mathrm{C}$, which is consistent with the farmland temperature in June and July; initial $\mathrm{pH}, 6.0-7.0$, which is consistent with the $\mathrm{pH}$ value of the soil for planting rice; and photoperiod, $24 \mathrm{~h}$. Moreover, $P$. aristosporum is easy to release zoospores, propagates and disperses at high temperature and humidity (Feng and Dernoeden 1999; Titone et al. 2009). Based on this, summer is the fastest growing period of $P$. aristosporum in Heilongjiang Province, we should prevent and control in advance to reduce the occurrence of the disease. Moreover, we found that the optimum carbon and nitrogen sources were starch and glycine, respectively. These results may help to develop effective strategy for the disease. These results deepen our understanding of $P$. aristosporum and lay a foundation for formulating effective measures in the future.

Pythium can cause pre- and/or post-emergence seedling damping off, as well as root, seed, or fruit rot on almost all cereals and grasses such as wheat, maize, and rice (Hendrix and Campbell 1973; van der Plaats-Niterink 1981; Santosh 2012). P. aristosporum can infect many plants including wheat (Triticum aestivum L.) (Lipps and Bruehl 1978), snap beans (Phaseolus vulgaris L.) (Kobriger and Hagedorn 1984), konnyaku (Amorphophallus konjac C. Koch) (Iwaizako 1987), turf grass (Titone et al. 2009), and maize (Zea mays L.) (Jin et al. 2019) and cause diseases. Moreover, improper crop rotation and farm practices may reduce crop yields. In this study, six common fruits and eight common crop seedlings in Northeast China were selected for host range determination. The results showed that $P$. aristosporum causing rice seedling blight can infect tomato, carrot, sweet potato, cucumber, and zucchini, as well as seedlings of broad bean, red bean, snailflower, soybean, mung bean, kidney bean, and hyacinth bean. Conversely, cabbage and maize seedling showed no signs of infection, which is a result different from that in Jin's study demonstrating that $P$. aristosporum can infect maize and show obvious signs. This may be due to the geographical differences that make our research environment different. Generally, maize diseases are mostly caused by multiple pathogens (Shan 2018), and single pathogens that cause disease may be affected by environmental conditions. So Jin and I get different results. Based on the above experimental results, farmers in Northeast China can potentially rotate cabbage or maize and rice to avoid large-scale outbreaks of diseases caused by P. aristosporum in the field.

P. aristosporum infects plants can result in serious yield loss (Kageyama 2014). At present, disease control depends mainly on the application of chemical fungicides. Mazzola and Cook (1991) found that metalaxyl can effectively control diseases caused by $P$. aristosporum in wheat. In recent years, mefenoxam, fosetyl-aluminum and propamocarb have also been used to control diseases caused by $P$. 
aristosporum, but Titone et al. (2008) found that $P$. aristosporum strains had low sensitivity to the three fungicides. These results may be attributed to the repeated use of the same fungicides under high disease pressure conditions. In this study, we selected five common fungicides in Northeast China that were not used to control diseases caused by $P$. aristosporum to test sensitivity. The results showed that the $\mathrm{EC}_{50}$ value of fludioxonil, prochloraz, carbendazim, hymexazol and azoxystrobin were $0.0731,0.2391$, $1.0281,8.0474$ and $11.0102 \mu \mathrm{g} / \mathrm{ml}$, respectively. In other words, fludioxonil had the strong inhibitory effect on $P$. aristosporum and azoxystrobin had the weakest inhibitory effect. Therefore, we consider using fludioxonil to control rice seedling blight caused by $P$. aristosporum in Heilongjiang Province. In future studies, field trials should be conducted to determine the true effects of fludioxonil on rice seedling blight caused by P. aristosporum.

In summary, this is the first report of $P$. aristosporum causing rice seedling blight in China. We observed that $P$. aristosporum has good adaptability to the environment, and seedling blight caused by $P$. aristosporum can significantly reduce survival rates and healthy seedlings of rice; as such, its distribution needs to be investigated and effective disease management strategies need to be developed.

\section{Conclusion}

In this study, this is the first report of $P$. aristosporum causing rice seedling blight in China. Fludioxonil is a relatively sensitive chemical fungicide against $P$. aristosporum. $P$. aristosporum causing rice seedling blight has a good environmental adaptability and a wide range of hosts, which poses a great threat to rice seedling production. Occurrence of the new disease caused by $P$. aristosporum should give full consideration for the use of proper disease management to protect rice.

\section{Materials And Methods}

\section{Isolation and pathogenicity of the pathogen}

Rice seedling blight samples collected in Heilongjiang Province were used for pathogen isolation and identification. A published tissue isolation method ( $\mathrm{Li}$ et al. 2019) was used to isolate and culture the pathogens on potato dextrose agar (PDA) at $25^{\circ} \mathrm{C}$ for 5 days.

The submerged roots method (Wang et al. 2019) was performed in pots and was used to assess the pathogenicity of the fungal cultures according to Koch's postulates (Shi et al. 2015). Fungi were then reisolated from diseased rice plants and observed. Specifically, the roots of 15-day-old rice seedlings (cv. Longdao 18) were submerged for $10 \mathrm{~min}$ in a suspension containing $10^{6} \mathrm{conidia} / \mathrm{ml}$ (Li et al. 2019). Then, the treated seedlings were sown in pots, with five seedlings in each pot, repeated three times. Seedlings soaked in sterilized water were used as control. After 20 days, observed whether the symptoms of the inoculated seedlings were consistent with those of the original isolated.

\section{Identification of the pathogen}


Based on morphological characteristics (Wei 1979) and molecular identification, isolates causing rice seedling blight were identified. To further determine the genus and species of the isolates, genomic DNA was extracted from the mycelium of representative isolates using Tiangen Genome Extraction Kit (Tiangen Biotech, Beijing, China). Next, the internal transcribed spacer region (ITS) was amplified and sequenced using ITS1/ITS4 primers (White et al. 1990; Lookabaugh et al. 2017). PCR was carried out in a final volume of $50 \mu \mathrm{L}$, with $10 \mu \mathrm{M}$ of each primer, $2 \times$ Taq Master Mix and $10 \mathrm{ng}$ of template DNA. PCR conditions were initial denaturation at $94^{\circ} \mathrm{C}$ for $5 \mathrm{~min}$, followed by 36 cycles of $94^{\circ} \mathrm{C}$ for $1 \mathrm{~min}, 58^{\circ} \mathrm{C}$ for 1 $\mathrm{min}, 72^{\circ} \mathrm{C} 1.5 \mathrm{~min}$, and final extension at $72{ }^{\circ} \mathrm{C}$ for $10 \mathrm{~min}$. PCR products were purified and sequenced by Shanghai Biological Engineering Co., Ltd (Shanghai, China). Phylogenetic trees of representative isolates were constructed using PhyML version 3.0 based on the maximum-likelihood principle (Guindon et al. 2010).

\section{Biological characteristics}

Using the mycelial growth rate method (Li et al. 2020), single factor testing was performed in PDA medium with different $\mathrm{pH}$ levels $(4.0,6.0,8.0$, and 10.0$)$, temperatures $\left(10^{\circ} \mathrm{C}, 20^{\circ} \mathrm{C}, 25^{\circ} \mathrm{C}, 28^{\circ} \mathrm{C}, 30^{\circ} \mathrm{C}\right.$, and $35^{\circ} \mathrm{C}$ ) and photoperiods (light $24 \mathrm{~h}$, light/dark $=12 \mathrm{~h} / 12 \mathrm{~h}$, and dark $24 \mathrm{~h}$ ). Single-factor testing was performed using initial medium (agar powder $20 \mathrm{~g}$, soluble starch $10 \mathrm{~g}$, peptone $10 \mathrm{~g}$, distilled water 1000 $\mathrm{ml}, \mathrm{pH}$ 7.0-7.2) with a carbon source (an equal amount of lactose, glucose, mannitol, maltose, fructose, or sucrose) replacing soluble starch in the initial medium, and a nitrogen source (an equal amount of ammonium sulfate, ammonium nitrate, potassium nitrate, ammonium chloride, glycine, or sodium nitrate) replacing peptone in the initial medium. Each treatment was repeated thrice. Under the above conditions, the diameters of the colonies formed by the isolates were measured.

\section{Host range determination}

Fruits and plants, including tomato, carrot, sweet potato, cucumber, zucchini, and cabbage, as well as seedlings of broad bean, red bean, snailflower, soybean, mung bean, kidney bean, hyacinth bean, and maize, were selected to test the host range of the pathogenic fungi. The aforementioned fruits and plants (10 fruits or plants/each treatment) were inoculated with $1 \mathrm{ml}$ conidial suspension of the isolates $\left(1 \times 10^{6}\right.$ spores/ml) by injection (Posada et al. 2007), respectively. Ten other fruits and plants were injected with 1 $\mathrm{ml}$ of sterile distilled water as control. After 5 days of inoculation, the disease incidence on the fruit and plant seedlings was analyzed.

\section{Sensitivity test of pathogenic fungi to fungicides}

The mycelial growth rate method (Jiang et al. 2015) was used to determine the pathogenic fungi sensitivity to the following fungicides: hymexazol (80\% WP) [North American Nongda Conglomerate, Shanghai, China], fludioxonil (50\% WP) [Syngenta (Suzhou) Crop Protection Co., Ltd., Suzhou, China], prochloraz (45\% EW) [Donghe Biological, Shandong, China], carbendazim (50\% WP) [Jiansu Pesticide Chemical Co., Ltd, Zhenjiang, China], and azoxystrobin (19\% Suspension Emulsion) [Adama (Beijing) Agricultural Technology Co., Ltd, Beijing, China]. 
Through a pilot study, hymexazol was added to PDA at final concentrations of $0.5 \mu \mathrm{g} / \mathrm{ml}, 1 \mu \mathrm{g} / \mathrm{ml}, 3$ $\mu \mathrm{g} / \mathrm{ml}, 5 \mu \mathrm{g} / \mathrm{ml}$, and $10 \mu \mathrm{g} / \mathrm{ml}$; Fludioxonil at $0.05 \mu \mathrm{g} / \mathrm{ml}, 0.1 \mu \mathrm{g} / \mathrm{ml}, 0.3 \mu \mathrm{g} / \mathrm{ml}, 0.5 \mu \mathrm{g} / \mathrm{ml}$, and $1 \mu \mathrm{g} / \mathrm{ml}$; Prochloraz at $0.5 \mu \mathrm{g} / \mathrm{ml}, 1 \mu \mathrm{g} / \mathrm{ml}, 3 \mu \mathrm{g} / \mathrm{ml}, 5 \mu \mathrm{g} / \mathrm{ml}$, and $10 \mu \mathrm{g} / \mathrm{ml}$; Carbendazim at $0.5 \mu \mathrm{g} / \mathrm{ml}, 1 \mu \mathrm{g} / \mathrm{ml}, 3$ $\mu \mathrm{g} / \mathrm{ml}, 5 \mu \mathrm{g} / \mathrm{ml}$, and $10 \mu \mathrm{g} / \mathrm{ml}$; Azoxystrobin at $4 \mu \mathrm{g} / \mathrm{ml}, 5 \mu \mathrm{g} / \mathrm{ml}, 6 \mu \mathrm{g} / \mathrm{ml}, 8 \mu \mathrm{g} / \mathrm{ml}$, and $10 \mu \mathrm{g} / \mathrm{ml}$. Fungicide-containing PDA plates were made according to the above concentrations. Three plates were used for each treatment, and the experiment was conducted twice. PDA plates with an equal volume of sterile water were used as control. Each treatment was repeated thrice. A mycelial plug $(0.7 \mathrm{~cm}$ diameter $)$ with the pathogenic fungi was placed at the center of a PDA plate and was incubated in the dark at $25^{\circ} \mathrm{C}$ for $120 \mathrm{~h}$. The colony diameter was then measured to calculate the growth inhibition rate.

\section{Data analysis}

Analysis of variance (ANOVA) was performed using SPSS Statistics 20.0 (IBM/SPSS, Chicago, IL, USA). Treatment means were assessed using Duncan's multiple range test $(P=0.05)$.

\section{Declarations}

\section{Acknowledgements}

We thank members of the laboratory for assistance in the field

\section{Authors' Contributions}

Conceived and designed experiments: LJX, LYG. Performed experiments: LJX, XCZ, HWB; Analyzed data: LJX, LYG. Wrote and revised manuscript: LJX and LYG. All authors read and approved the final manuscript.

\section{Funding}

This study was financially supported by The National Natural Science Foundation of China (31971760) and the Heilongjiang Collaborative Innovation and Extension System of Modern Agricultural Industry Technology of Forage and Feed.

\section{Availability of Data and Materials}

All data generated or analyzed during this study are included in this published article.

\section{Ethics Approval and Consent to Participate}

Not applicable.

\section{Consent for Publication}

Not applicable. 


\section{Competing Interests}

The authors declare that they have no competing interests.

\section{References}

1. Ahuja R, Sidhu A, Bala A (2019) Synthesis and evaluation of iron(ii) sulfide aqua nanoparticles (FeSNPs) against Fusarium verticillioides causing sheath rot and seed discoloration of rice. Eur J Plant Pathol 155: 163-171 https://doi.org/ 10.1007/s10658-019-01758-3

2. Alaei $H$, Rostami $F$ (2013) Identification of cucumber damping-off based on morphological and molecular characterizations in Rafsanjan. Iran J Plant Path 48: 177-182

3. Aye SS, Fukuda S, Matsumoto M (2008) Chemotaxonomic characterization of rice seedling blight complex using fatty acid methyl ester (FAME) profiles. Mycoscience 49: 373-378 https://doi.org/10.1007/s10267-008-0431-7

4. Baek I, Kim MS, Cho BK, Mo C, Barnaby JY, McClung AM, Oh M (2019) Selection of optimal hyperspectral wavebands for detection of discolored, diseased rice seeds. Appl Sci-Basel 9:1027 https://doi.org/10.3390/app9051027

5. Cao P, Li CX, Tan KF, Liu CZ, Xu X, Zhang SY, Wang XJ, Zhao JW, Xiang WS (2020) Characterization, Phylogenetic analyses, and pathogenicity of Enterobacter cloacae on rice seedlings in Heilongjiang Province, China. Plant Dis 104: 1601-1609 https://doi.org/10.1094/PDIS-12-19-2557-RE

6. Feng Y, Dernoeden PH (1999) Pythium species associated with root dysfunction of creeping bentgrass in Maryland. Plant Dis 83: 516-520 https://doi.org/ 10.1094/PDIS.1999.83.6.516

7. Foley MF, Deacon JW (1986) Physiological differences between mycoparasitic and plant-pathogenic Pythium spp. Transactions of the British. Mycol Soc 86: 225-231 https://doi.org/10.1016/S00071536(86)80149-8

8. Furuya H, Matsumoto T, Fuji S, Naito H (2003) Inconspicuous restraint of rice seedling growth by root-infecting fungi in soil of a rice paddy field. J Gen Plant Pathol 115-119 https://doi.org/10.1007/s10327-002-0023-x

9. Gao TC, Ye ZY, Wang M, Ma YM (2001). Identification and pathogenicity test of pathogenic Fusarium of rice blight. Chinese J Rice Sci 15: 81-83

10. Guindon S, Dufayard JF, Lefort V, Anisimova M, Hordijk W, Gascuel O (2010) New Algorithms and Methods to Estimate Maximum-Likelihood Phylogenies: Assessing the Performance of PhyML 3.0. Syst Biol 59: 307-321 https://doi.org/ 10.1093/sysbio/syq010

11. Guo M, Zhou YN, Xiao Q, Li BD, Liang C (2019) The pathogen causing Pythium root rot of Chinese cabbage. Mygosystema 38: 761-767

12. Hendrix FF, Campbell WA (1973) Pythium as plant pathogens. Annu Rev Phytopathol 11: 77-98 https://doi.org/10.1146/annurev.py.11.090173.000453 
13. Huang SW, Su XQ (2007) Biological studies on Pythium guiyangense, a fungal pathogen of mosquito larvae. Mygosystema 26: 380-388 https://doi.org/10.3969/j.issn.1672-6472.2007.03.009

14. Imolehin ED (1983) Rice seed borne fungi and their effect on seed germination. Plant Dis 67:1334$1336 \mathrm{https} / / /$ doi.org/10.1094/PD-67-1334

15. Iwaizako C (1987) Study on the ecology and control of konnyaku (Amorphophallus konjac C. Koch) root rot. Spec Bull Ibaraki Agric Exp Stn 5: 1-114 (in Japanese with English summary)

16. Jiang N, Hu FY, Ye YF (2015) Pathogen identification of a new disease in Siraitia grosvenorii and screening of effective fungicides. Plant Protect 41: 173-177

17. Jin LY, Li MS, Wang ZW, Shi J, Guo N, Liu SS, Zhang HJ (2019) Resistance identification and genetic diversity analysis of American maize inbred lines to four pathogenic stalk rot diseases. J Plant Genet Resour 20: 1428-1437

18. Kageyama K (2014) Molecular taxonomy and its application to ecological studies of Pythium species. J Gen Plant Pathol 80: 314-326 https://doi.org/10.1007/s10327-014-0526-2

19. Klemsdal SS, Herrero ML, Wanner LA, Lund G, Hermansen A (2008) PCR-based identification of Pythium spp. causing cavity spot in carrots and sensitive detection in soil samples. Plant Pathol 57: 877-886 https://doi.org/10.1111/j.1365-3059.2008.01839.x

20. Kobriger K, Hagedorn DJ (1984) Additional Pythium species associated with the bean root rot complex in Wisconsin's central sands. Plant Dis 68: 595-596 https://doi.org/ 10.1094/PD-69-595

21. Li JX, Zhang YW (2020) Biological characteristics and isolation of Pythium ultimum causing rot of Chinese cabbage. Australas Plant Path 49: 201-207 https://doi.org/ 10.1007/s13313-020-00692-x

22. Li WX, Li HY, Cai DL, Sang HY, Chen TY (2016) The induced-resistance of harpin on rice seedling blight. J Anhui Agri Sci 44:186-187

23. Li YG, Cai YN, Liang YB, Ji PS, Xu LK (2020) Assessment of antifungal activities of a biocontrol bacterium BA17 for managing postharvest gray mold of green bean caused by Botrytis cinerea. Postharvest Biol Tec 161: 111086 https://doi.org/ 10.1016/j.postharvbio.2019.111086

24. Li YG, Zhang X, Zhang R, Liu J X, Ali E, Ji P S, and Pan H Y (2019) Occurrence of seedling blight caused by Fusarium tricinctum on rice in China. Plant Dis 10:1789 https://doi.org/10.1094/PDIS-1018-1835-PDN

25. Ling Y, Xia J, Koji K, Zhang X, Li Z (2018) First Report of Damping-Off Caused by Pythium arrhenomanes on Rice in China. Plant Dis 102: 2382-2383 https://doi.org/ 10.1094/PDIS-01-180113-PDN

26. Lipps PE, Bruehl GW (1978). Snow rot of winter wheat in Washington. Phytopathology 68: 1120-1127 https://doi.org/10.1094/Phyto-68-1120

27. Liu F, Mu W, Zhang WJ, Zhang J (2004) Control of rice blight on dry nursery seedling by fungicide and physiological regulation on rice seedling. Chin J pestic Ence 6: 37-42

28. Liu HL (2017) Assessment of artificial selection in maize (Zea mays L.) and Asian rice (Oryza sativa L.) using QTL data. Genet Resour Crop Ev 64: 1561-1568. https://doi.org/10.1007/s10722-016-0454- 
29. Liu JX, Cai YN, Jiang WY, Li YG, Zhang QF, Pan HY (2020) Population structure and genetic diversity of fungi causing rice seedling blight in Northeast China based on microsatellite markers. Plant Dis 104: 868-874 https://doi.org/10.1094/PDIS-08-19-1620-RE

30. Lookabaugh E, Shew B, Cowger C (2017) Three Pythium species isolated from severely stunted wheat during an outbreak in North Carolina. Plant Health Prog 18: 169-173 https://doi.org/10.1094/PHP-03-17-0015-RS

31. Ma B, Wang JH, Liu CZ, Hu JF, Tan KF, Zhao FY, Yuan M, Zhang JH, Gai ZJ (2019) Preventive effects of fluoro-substituted benzothiadiazole derivatives and chitosan oligosaccharide against the rice seedling blight induced by Fusarium oxysporum. Plants-Basel 8: 538 https://doi.org/10.3390/plants8120538

32. Mazzola M, Cook RJ (1991) Effects of fungal root pathogens on the population dynamics of biocontrol strains of fluorescent pseudomonads in the wheat rhizosphere. Applied and Environmental Microbiology+ 57: 2171-2178 https://doi.org/ 10.1002/bit.260380413

33. Meng Y, Hui ZB, Wu S, Li SM, Zheng ZJ, Zheng F, Wang MS, Nan P (2008) Main rice diseases and their control in Heilongjiang Province. Modern Agric 3: 6-8

34. Mostowfizadeh-Ghalamfarsa R, Banihashemi Z (2005) Identification of soil Pythium species in Fars province of Iran. Iran J Sci Technol A 29: 79-87

35. Motschenbacher JM, Brye KR, Anders MM, Gbur EE (2014) Long-term rice rotation, tillage, and fertility effects on near-surface chemical properties in a silt-loam soil. Nutr Cycl Agroecosys 100: 77-94 https://doi.org/10.1007/s10705-014-9628-7

36. Naima B, Najwa B, Souli M (2020) Pythium species associated with die-back apple trees and citrus gummosis in Tunisia. Pythium Diagnosis, Diseases and Management. 1st Edition: Chapter 6

37. Nguyen TT, Chon TS, Kim J, Seo YS, Heo M (2017) Comparative and bioinformatics analyses of pathogenic bacterial secretomes identified by mass spectrometry in Burkholderia species. $J$ Microbiol 55: 568-582 https://doi.org/10.1007/s12275-017-7085-0

38. Ni SF, Song JR, Liu LL, Shao XW (2015) Formulation screening of metalaxyl· prochloraz thiram to control rice seedling blight. J Jilin Agric Univ 37: 287-289, 295

39. Posada F, Aime MC, Peterson SW (2007) Inoculation of coffee plants with the fungal entomopathogen Beauveria bassiana (Ascomycota: Hypocreales). Mycol Res 111: 748-757 https://doi.org/10.1016/j.mycres.2007.03.006

40. Qian Y, Matsumoto H, Li WZ, Zhu GN, Hashidoko Y, Hu Y, Wang MC (2016) Genome sequence of Burkholderia plantarii ZJ171, a tropolone-producing bacterial pathogen responsible for rice seedling blight. Microbiol Resour Announc 4 https://doi.org/ 10.1128/genomeA.01318-16

41. Riera-Ruiz CA, Castro-Lara J, Feijoo MIJ, Cevallos-Cevallos J (2018) Burkholderia gladioli can inhibit Burkholderia glumae in rice seedlings affected with bacterial panicle blight. Phytopathology 108 : $142-142$ 
42. Robideau GP, de Cock AWAM, Coffey MD, Voglmayr H, Brouwer H, Bala K, Chitty DW, Désaulniers N, Eggertson QA, Gachon CMM, Hu C, Küpper FC, Rintoul TL, Sarhan E, Verstappen ECO, Zhang Y, Bonants PJM, Ristaino JB, Lévesque CA (2011) DNA barcoding of oomycetes with cytochrome $c$ oxidase subunit I and internal transcribed spacer. Mol Ecol Resour 11:1002-1011 https://doi.org/10.1111/j.1755-0998.2011.03041.x

43. Rojas JA, Jacobs JL, Napieralski S, Karaj B, Bradley CA, Chase T, Esker PD, Giesler LJ, Jardine DJ, Malvick DK, Markell SG, Nelson BD, Robertson AE, Rupe JC, Smith DL, Sweets LE, Tenuta AU, Wise KA, Chilvers MI (2016) Oomycete species associated with soybean seedlings in North America-Part I: Identification and pathogenicity characterization. Phytopathology 107: 280-292 https://doi.org/ 10.1094/PHYTO-04-16-0176-R

44. Santosh KB (2012) The pathogenicity of different Pythium spp. on aerobic rice seedlings. J Bangladesh Soc Agric Sci Technol 9: 83-87

45. Shan LY (2018) Identification and diversity analysis of Fusarium Spp. causing maize stem rot disease. Beijing: Chinese Academy of Agricultural Sciences.

46. Shi JL, Li YQ, Hu KM (2015) Isolation and identification of pathogens from rotted root of Pinellia ternata in Guizhou Province. Microbiology 42: 289-299

47. Shindell D, Faluvegi G, Kasibhatla P, Van DR (2019) Spatial patterns of crop yield change by emitted pollutant. Earths Future 7: 101-112 https://doi.org/ 10.1029/2018EF001030

48. Spence C, Alff E, Johnson C, Ramos C, Donofrio N, Sundaresan V, Bais H (2014) Natural rice rhizospheric microbes suppress rice blast infections. Bmc Plant Biol 14: 130 https://doi.org/10.1186/1471-2229-14-130

49. Temgot JC, and Xu T (1996) Effect of Different Carbohydrates and Nitrogen Sources on the Behaviour of Pythium Isolates. J Zhejiang Agric Univ 22: 53-55

50. Titone P, Mocioni M, Garibaldi A, Gullino ML (2009) Fungicide failure to control Pythium blight on turf grass in Italy. J Plant Dis Protect 116: 55-59 https://doi.org/ 10.1007/BF03356286

51. van der Plaats-Niterink AJ (1981) Monograph of the genus pythium. Stud Mycol 21:1-242

52. Van BE, Hofte M (2013) Pythium species from rice roots differ in virulence, host colonization and nutritional profile. Bmc Plant Biol 13: 203 https://doi.org/ 10.1186/1471-2229-13-203

53. Verma G, Mondal KK, Kulshreshtha A, Sharma M (2019) XopR T3SS-effector of Xanthomonas oryzae pv. oryzae suppresses cell death-mediated plant defense response during bacterial blight development in rice. 3 Biotech 9: 272 https://doi.org/ 10.1007/s13205-019-1802-9

54. Verma SK, Kingsley KL, Bergen MS, Kowalski KP, White JF (2018) Fungal disease prevention in seedlings of rice (Oryza sativa) and other grasses by growth-promoting seed-associated endophytic bacteria from invasive phragmites australis. Microorganisms 6 https://doi.org/10.3390/microorganisms6010021

55. Wang HD, Chen JP, Yan CQ, Shen Y (2017) Occurrence, epidemics dynamic, green prevention and control technology of rice bacterial leaf blight in Southern China. Acta Agric Zhejiangensis 29: 20512059 
56. Wang M, Wei P, Cao M, Zhu L, Lu Y (2016) First report of rice seedling blight caused by Burkholderia plantarii in North and Southeast China. Plant Dis 100: 645-646 https://doi.org/10.1094/PDIS-07-150765-PDN

57. Wang S, Sun L, Li WQ, Liu JX, Li YG, Wei D (2019) First report of seedling blight caused by Fusarium redolens on rice in Northeast China. Plant Dis 103: 1418 https://doi.org/10.1094/PDIS-10-18-1783PDN

58. Wei JC (1979) Handbook of Fungus Identification. Shanghai: Shanghai Scientific.

59. White TJ, Bruns T, Lee S, Taylor JW (1990) Amplification and direct sequencing of fungal ribosomal RNA genes for phylogenetics. Pcr Protocols: A Guide to Methods \& Application 315-322

60. Yu S, Tian L (2018) Breeding major cereal grains through the lens of nutrition sensitivity. Mol Plant 11: 23-30. https://doi.org/10.1016/j.molp.2017.08.006

\section{Figures}




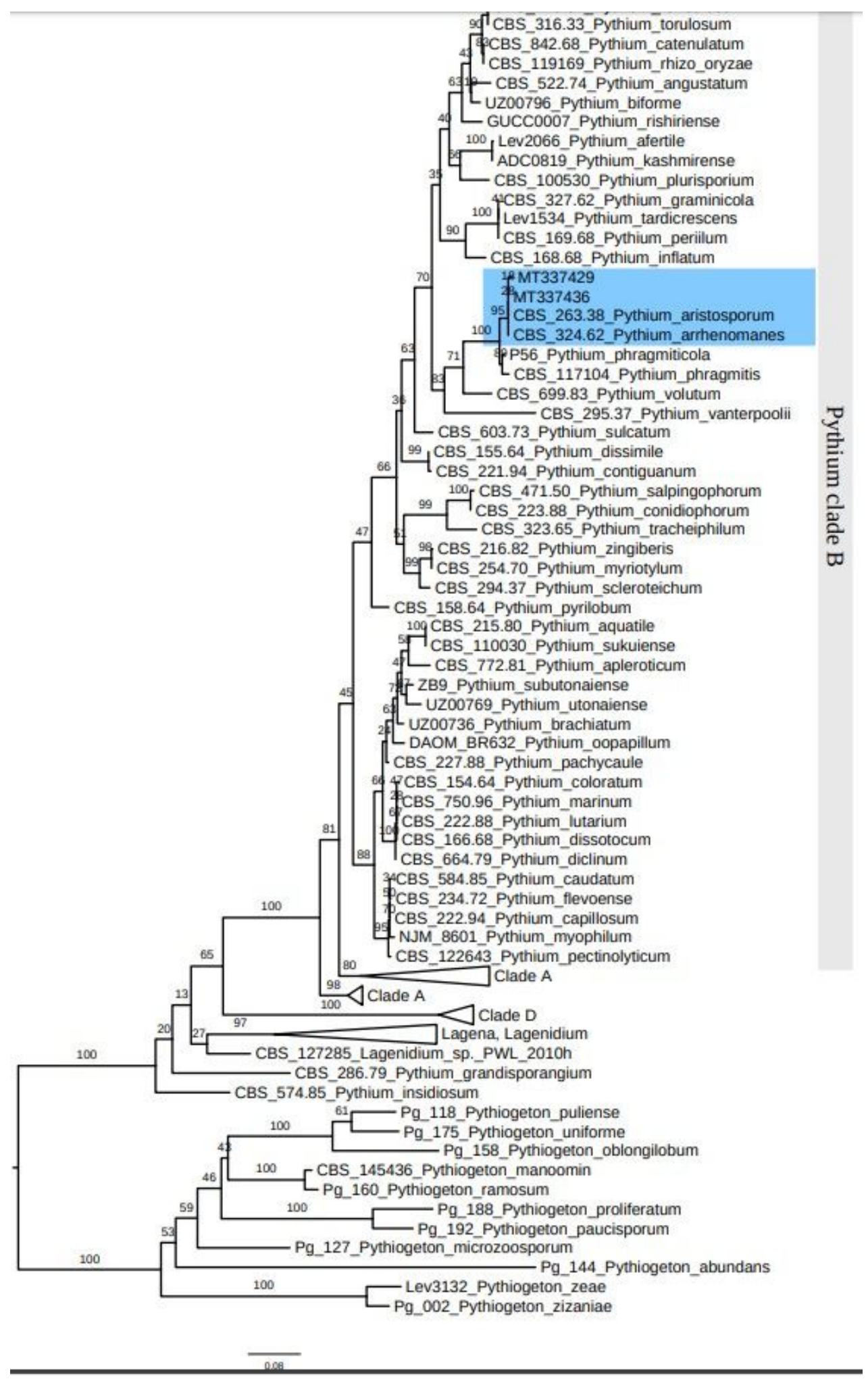

\section{Figure 1}

Phylogenetic tree of Pythium aristosporum strains JS22 and SH1 of Rice seedling blight based on internal transcribed spacer regions (ITS) gene. The bootstrap values on the branching nodes were calculated on 1000 replications. The scale bar indicated 0.08 substitutions per nucleotide position. 

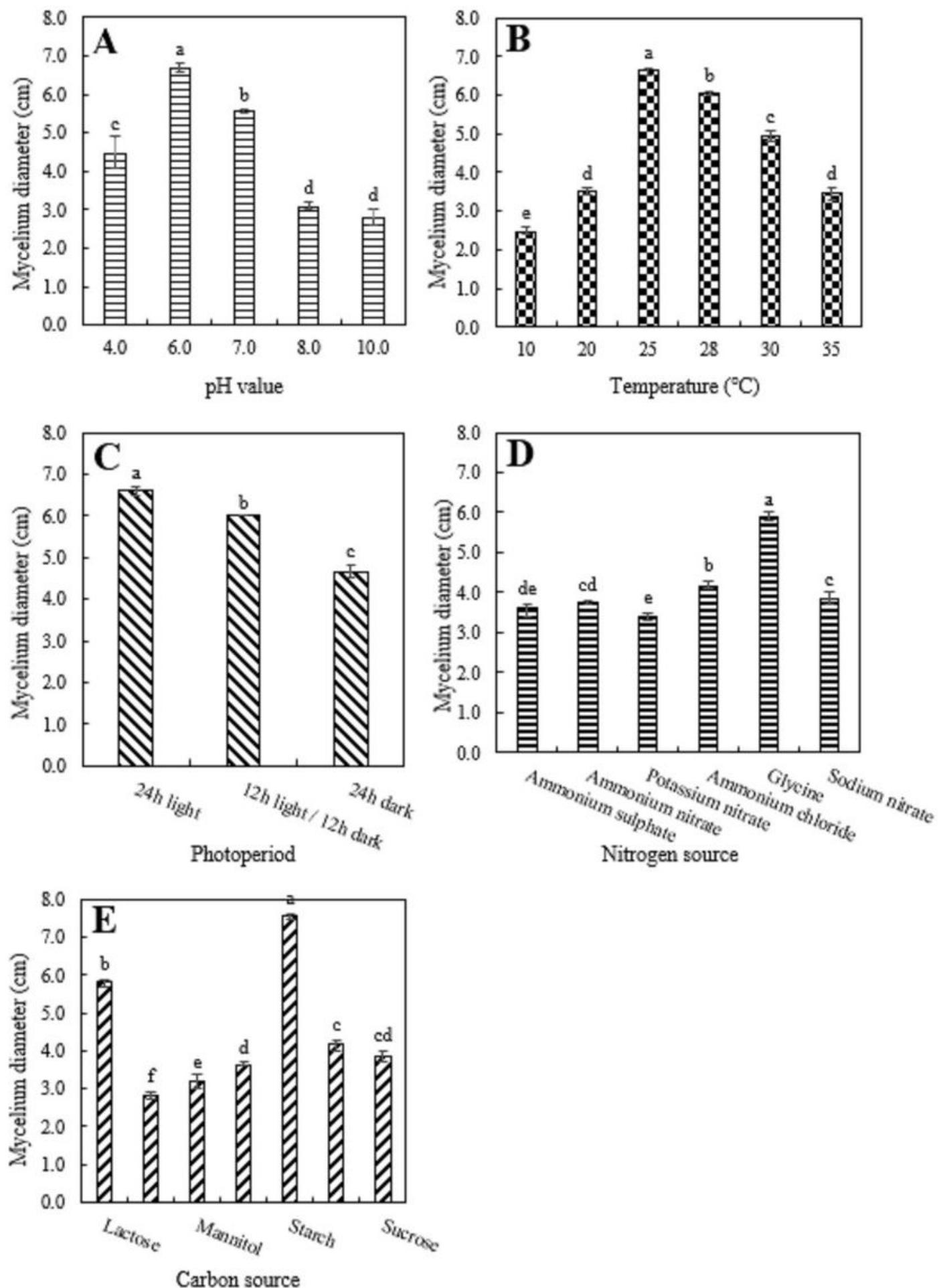

Figure 2

Mycelium growth diameter of Pythium aristosporum strain JS22 at different pH values, temperatures, illuminations, nitrogen sources and carbon sources. Different letters above the bars indicate significant difference according to Duncan's multiple range test $(P=0.05)$. 


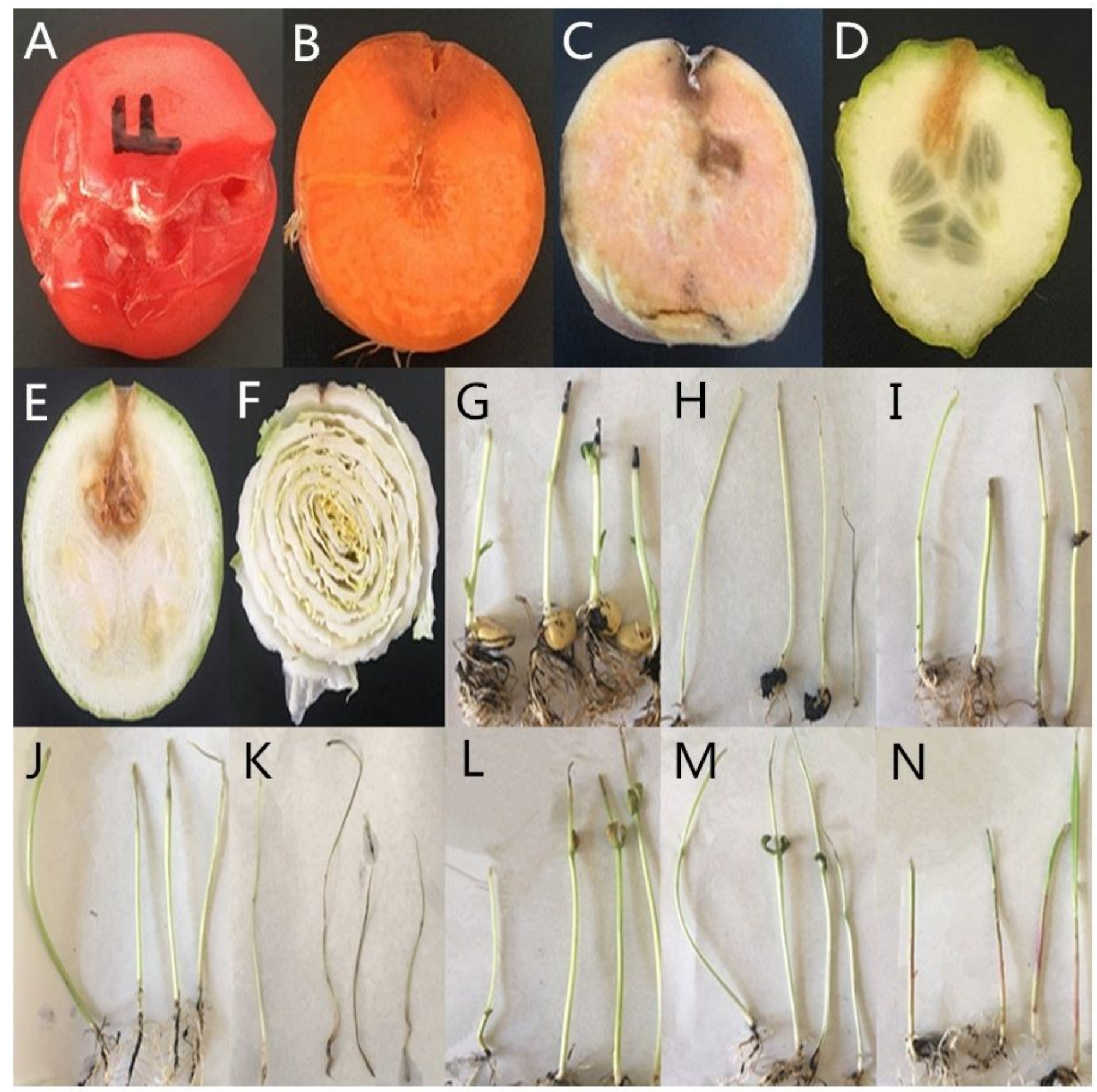

Figure 3

Host range of Pythium aristosporum determined. A: tomato (Solanum lycopersicum). B: carrot (Daucus carota L.). C: sweet potato (Ipomoea batatas). D: cucumber (Cucumis sativus L.). E: zucchini (Cucurbita pepo L.). F: cabbage (Brassica oleracea L.). G: broad bean (Vicia faba L.) seedlings. H: red bean (Vigna angularis) seedlings. I: snailflower (Lablab purpureus (L.) Sweet) seedlings. J: soybean (Glycine max) seedlings. K: mung bean (Vigna radiata) seedlings. L: kidney bean (Phaseolus vulgaris) seedlings. M: hyacinth bean (Dolichos lablab L.) seedlings. N: maize (Zea mays L.) seedlings. 